\title{
Downstream changes in spring-fed stream invertebrate communities: the effect of increased temperature range?
}

\author{
José BARQUÍN* and Russell G. DEATH ${ }^{1)}$ \\ Instituto de Hidráulica Ambiental, Departamento de Ciencias y Técnicas del Agua y del Medio Ambiente, GESHA, Universidad de \\ Cantabria, 39005 Santander, Spain \\ ${ }^{1)}$ Institute of Natural Resources, Ecology, Massey University, Private Bag 11222, Palmerston North, New Zealand \\ *e-mail corresponding author: barquinj@unican.es
}

\begin{abstract}
Reduced thermal amplitude has been highlighted as a limiting factor for aquatic invertebrate diversity in springs. Moving downstream water temperature range increases and invertebrate richness is expected to change accordingly. In the present study temperature patterns were investigated in seven spring-fed streams, between April 2001 and November 2002, and compared to five run-off-fed streams to assess the degree of crenic temperature constancy. Temperature and physico-chemical characteristics of the water, and food resource levels were measured, and the invertebrate fauna collected at 4 distances $(0,100,500 \mathrm{~m}$ and $1 \mathrm{~km})$ from seven springs in the North and South Islands of New Zealand. Temperature variability was greater for run-off-fed streams than for springs, and increased in the spring-fed streams with distance from the source. Periphyton and physico-chemical characteristics of the water did not change markedly over the $1 \mathrm{~km}$ studied, with the exception of water velocity and organic matter biomass, which increased and decreased, respectively. The rate of increase in temperature amplitude differed greatly for the studied springs, probably being affected by flow, altitude, and the number and type of tributaries (i.e., spring-or run-off-fed) joining the spring-fed stream channel. Longitudinal changes in the number and evenness of invertebrate taxa were positively correlated to thermal amplitude $\left(\mathrm{r}_{\mathrm{s}}=0.8\right)$. Moving downstream, invertebrate communities progressively incorporated taxa with higher mobility and taxa more common in nearby run-off-fed streams. Chironomids and non-insect taxa were denser at the sources. Chironomid larvae also numerically dominated communities 100 and $500 \mathrm{~m}$ downstream from the sources, together with Pycnocentria spp. and Zelolessica spp., while taxa such as Hydora sp. and Hydraenidae beetles, the mayflies Deleatidium spp. and Coloburiscus humeralis, and the Trichoptera Pycnocentrodes spp., all had greater abundances $1 \mathrm{~km}$ from the sources. In conclusion, water temperature range was highly correlated with number of taxa, although other factors, such as substratum composition, stability and invertebrate drift, may also play an important role in the determination of longitudinal changes in invertebrate community composition and structure along spring-fed streams.
\end{abstract}

Key words: Diversity, longitudinal patterns, freshwater springs, thermal constancy

\section{INTRODUCTION}

One of the main characteristics of running waters is their unidirectional transport of materials and organisms along the longitudinal stream gradient (Hynes 1970). The composition and structure of stream biotic communities have been shown to change in response to longitudinal changes in habitat characteristics, such as temperature, current velocity, depth, width, discharge, substratum, turbidity and food availability (Hynes 1970; Fisher 1982; Allan 1996). Early observations of spatial changes in stream communities from headwaters to large rivers prompted the division of running waters into Cryon, Crenon, Rhithron and Potamon biocoenoses (Hynes 1970; Hawkes 1975; Ward 1994). Cryal and crenal zones are the uppermost reaches of glacier- and spring-fed streams, respectively, while the rhithral zone includes the upper parts of snow and run-off-fed streams (Ward 1994). The idea of a longitudinal change along the stream gradient, culminated in the formulation of the river continuum concept (Vannote et al. 1980); this has been the focus of much discussion elsewhere (Hawkins
\& Sedell 1981; Winterbourn et al. 1981; Statzner \& Higler 1985; Perry \& Schaeffer 1987).

Cryal biotopes are characterized by a distinct and predictable change in invertebrate faunal assemblage, in which diversity increases downstream as thermal amplitude and physical stability increase (Milner \& Petts 1994; Ward 1994; Milner et al. 2001; but see Maiolini \& Lencioni 2001). However, downstream invertebrate community patterns are not as distinctive in crenal biotopes. The difficulty of establishing a general pattern for changes in invertebrate communities in crenal biotopes may be related to the more diverse nature of their groundwater supply compared with glaciers.

Furthermore, crenal biotopes may be found at different altitudes for a given latitude, while cryal biotopes are not (Ward 1994; Barquín \& Death 2004, 2006). The thermal characteristics of crenic sources, which include diurnal and seasonal constancy, summer-cold and winter-warm conditions, and delayed thermal maxima, can have a variety of effects on stream invertebrate fauna (Sweeney \& Vannote 1978; Vannote \& Sweeney 1980; Ward \& Stanford 1982). For example, in stream sec- 
Tab. 1. Study sites in the North and South Island of New Zealand and available water temperature and longitudinal invertebrate community data.

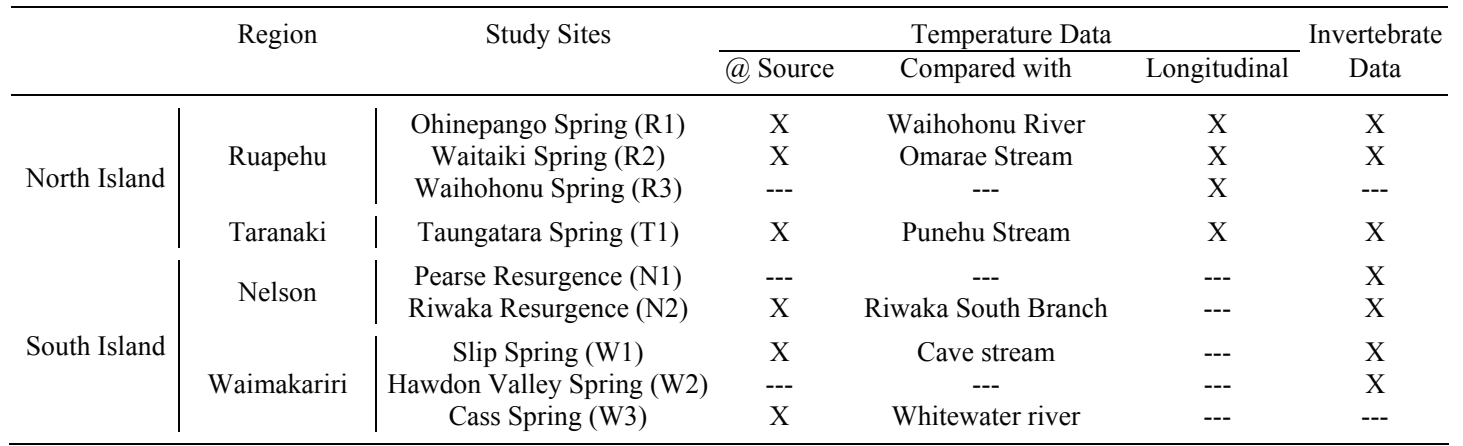

tions below dams and reservoirs, thermal constancy has been shown to be an important factor contributing to the suppression of certain insect taxa (Lehmkuhl 1972; Ward \& Stanford 1979; Vinson 2001). In general, the thermal and flow constancy of crenic sources has been shown to decrease invertebrate diversity compared with downstream reaches and nearby run-off-fed streams (Davidson \& Wilding 1943; Ward \& Dufford 1979; Meffe \& Marsh 1983; Erman \& Erman 1992; Barquín $\&$ Death 2004).

A recent study of 36 rheocrenic-spring-fed and runoff-fed streams in New Zealand, has shown that invertebrate communities from spring-fed streams are more diverse than those in nearby run-off-fed streams, mainly because of differences in substratum stability, amount of food resources, and habitat heterogeneity, although thermal constancy was not assessed (Barquín \& Death 2006). These results seem to contradict the generally observed pattern of reduced invertebrate diversity in springs, which is usually associated with their thermal constancy (Erman \& Erman 1992; Ferrington 1995a; McCabe 1998; but see Resh 1983). In this respect, spring-fed streams provide the opportunity to investigate longitudinal changes in macroinvertebrate assemblages in relation to changes in thermal regime without the influence of substratum instability. Thus, the first objective of this study is to assess whether a selection of New Zealand springs have larger thermal amplitudes than nearby run-off-fed streams. The second and main objective of the study was to investigate longitudinal changes in macroinvertebrate assemblages in spring-fed streams in relation to changes in thermal regime. Invertebrate diversity is hypothesized to be higher at sites with larger thermal ranges but without increased flow variability, for example, sites along a spring-fed stream without any major run-off-fed streams entering the main channel.

\section{METHODS}

\subsection{Study Sites}

Study sites comprised 9 freshwater spring-fed streams and 6 run-off-fed streams in New Zealand. Comparison of thermal regimes between sources and run-off-fed streams was performed using 6 pairs of springs and nearby run-off-fed streams, while downstream changes in temperature and macroinvertebrate assemblages were studied in 4 and 7 springs, respectively (Tab. 1). Spring-fed streams were selected from Tongariro (Ohinepango, Waitaiki and Waihohonu Springs in Ruapehu, R1-R3) and Mt Taranaki (Taungatara Spring, T1) National Parks in the North Island, and in the Waimakariri basin (Slip, Hawdon and Cass Springs, W1-W3) and Kahurangi National Park (Pearse and Riwaka Resurgences in Nelson, N1-N2) in the South Island of New Zealand. All spring-fed streams were fed by rheocrenic springs, where emerging water immediately forms a stream (Danks \& Williams 1991). The sources had a wide range of substratum composition, ranging from bedrock and large boulders (Riwaka and Pearse River Resurgences) to cobbles (Slip and Cass Spring) or sand, silt and mud (Ohinepango, Waitaiki Stream, Waihohonu Stream, Taungatara Stream and Hawdon Valley Springs). Although substratum at source was largely covered by bryophytes, downstream stony bottoms without macrophyte growth dominated. Streams ran through colluvial deposits (Waimakariri basin), karst regions (Kahurangi-Nelson), and volcanic areas (Ruapehu and Taranaki). The vegetation in the lower part of these regions is typical southern beech forest, except in Taranaki where it is Podocarp broadleaf forest. Stream altitude varied from 120 to $1100 \mathrm{~m}$ a.s.l., with sites at higher altitudes located in subalpine scrub (Ohinepango and Waitaiki Springs, R1 and R2).

\subsection{Physico-chemical measures}

A number of physico-chemical variables were measured between November and December 2001, concurrently with the invertebrate sampling. Conductivity and temperature were measured with an Orion 122 meter, and $\mathrm{pH}$ with a pHTestr 2 meter. In order to estimate flow, a stream transect at a random location was selected and five measures of current velocity were taken with a Flo-mate Marsh-McBirney 2000 at equidistant intervals. Width and depth were measured at five to seven points across these transects. A water sample was taken and analyzed in the laboratory for free inorganic nitrate and orthophosphate using ion chromatography in a Hach DR2000 UV/visible spectrophotometer. 
Ideally temperature regimes should have been recorded in all study sites, however, restrictions in the number of temperature data loggers, site accessibility and robbery prevented us from doing this. Thus, to record water temperature regimes, 6 temperature loggers (Onset, HOBO-H8) were placed within the first 30 $\mathrm{m}$ of 6 sources (R1, R2, T1, W1, W3 and N2; Tab. 1) and in 6 nearby run-off-fed streams (Omarae Stream and Waihohonu River in Ruapehu; Punehu Stream in Taranaki; Whitewater River and Cave Stream in Waimakariri; Riwaka South Branch Stream in Nelson) from May to November 2001. Temperature loggers were also used to assess longitudinal variation in temperature downstream from sources between April and November 2002. Loggers were placed within the first $30 \mathrm{~m}$, and, 1 $\mathrm{km}$ from the source of 2 springs (R1 and R3), and within the first $50 \mathrm{~m}$ and 1 and $2 \mathrm{~km}$ from the source in two other springs (R2 and T1). Loggers were set to record temperature hourly.

\subsection{Biological sampling}

Seven springs (R1, R2, T1, W1, W2, N1 and N2) were selected to study changes in macroinvertebrate fauna downstream from the source. Three $0.1 \mathrm{~m}^{2}$ Surber samples $($ mesh $=250 \mu \mathrm{m})$ were collected at random from each source and from 15-30 m rheophilic habitats, approximately $100 \mathrm{~m}, 500 \mathrm{~m}$ and $1 \mathrm{~km}$ downstream, during December 2001. Samples were preserved in $10 \%$ formalin and returned to the laboratory for identification to the lowest possible taxonomic level using available keys (Winterbourn et al. 2000). The fauna was grouped into functional feeding groups (FFG) following Cowie (1990), Death (1995) and Winterbourn (2000).

Coarse particulate organic matter $(\mathrm{CPOM},>1 \mathrm{~mm})$ and fine particulate organic matter (FPOM, 0.25-1 mm) remaining after invertebrates were removed were also dried to constant weight at $95{ }^{\circ} \mathrm{C}$, weighed and ashed at $550{ }^{\circ} \mathrm{C}$ for $2 \mathrm{~h}$ to yield ash free dry weight. Three stones (maximum planar dimensions: $30-80 \mathrm{~mm}$ ) were collected from each sampling location to assess periphyton biomass. Stones were kept frozen until pigments were extracted in $90 \%$ acetone at $5{ }^{\circ} \mathrm{C}$ for $24 \mathrm{~h}$ in darkness. Absorbance was read on a Varian-CARY 50 Conc. $\mathrm{UV} /$ visible spectrophotometer and converted to pigment concentration (chlorophyll- $a$ and phaeophytins) following Steinman \& Lamberti (1996). Total stone surface area was calculated using the equation of Graham et al. (1988). As only a part of the stone is exposed to light (we assumed half the total surface area), estimates of algal pigment concentration were corrected by dividing the total stone surface area in half.

\subsection{Statistical analysis}

We calculated Shannon's and rarified diversity values for each of our Surber samples using the PRIMER statistical package (Clarke \& Warwick 1994). The minimum number of individuals in our Surber samples was 41 , so species-richness was corrected to this number of animals. Surber samples were treated as replicates and differences in faunal parameters and resource levels were tested with two-way analysis of variance (ANOVA), with site and distance from the source as treatment levels. Both ANOVA factors were treated as fixed (SAS-Institute-Inc. 1988). In order to examine the longitudinal variation in fauna and resource variables in each spring, special attention was paid to the interaction between both main factors. If necessary, variables were logarithmically transformed to remove heteroscedasticity. Tukey's post hoc means test was used to determine where significant differences occurred, if the ANOVA revealed their presence (SAS-Institute-Inc. 1988).

The springs investigated in this study differed in altitude, flow and the number of tributaries joining the spring-fed stream channel, all characteristics which may affect longitudinal variation in temperature and invertebrate communities (Smith \& Lavis 1975; Crisp \& Howson 1982; Ward 1985). However, we were interested in looking at whether invertebrate community composition was related to the longitudinal gradient independent of location, so we pooled all sites and performed an analysis of similarities (ANOSIM) on invertebrate communities collected at $0,100,500$ and $1000 \mathrm{~m}$ from the source using the PRIMER statistical package (Clarke \& Warwick 1994). If ANOSIM indicates that there are differences in invertebrate community composition with distance from the source it means that the source : springfed stream gradient will be more important than the actual location of the source in determining invertebrate community composition. Bray-Curtis similarity distances were also calculated with the SIMPER procedure to compare crenic and spring-fed stream invertebrate communities at different distances from the source.

Source and spring-fed stream patterns of invertebrate community composition were also examined using non-metric multidimensional scaling (NMDS), using the PC-ORD statistical package (McCune \& Mefford 1995). The Sørensen distance measure was used to determine similarity between sites along the longitudinal gradient. Initial examination of stress patterns in the data suggested that three dimensions were appropriate for the final ordination, which was established with 500 iterations of the data. Relationships between the ordination axes and the measured environmental variables were examined using the Kendall rank correlation coefficient (SAS 1988).

\section{RESULTS}

\subsection{Physico-chemical characteristics}

\subsubsection{Temperature patterns of run-off and spring-fed streams}

Thermal range from May to November 2001 was higher in the run-off-fed streams, Cave Stream $\left(12{ }^{\circ} \mathrm{C}\right)$, Whitewater River $\left(11^{\circ} \mathrm{C}\right)$ and Waihohonu River $\left(8{ }^{\circ} \mathrm{C}\right)$. 

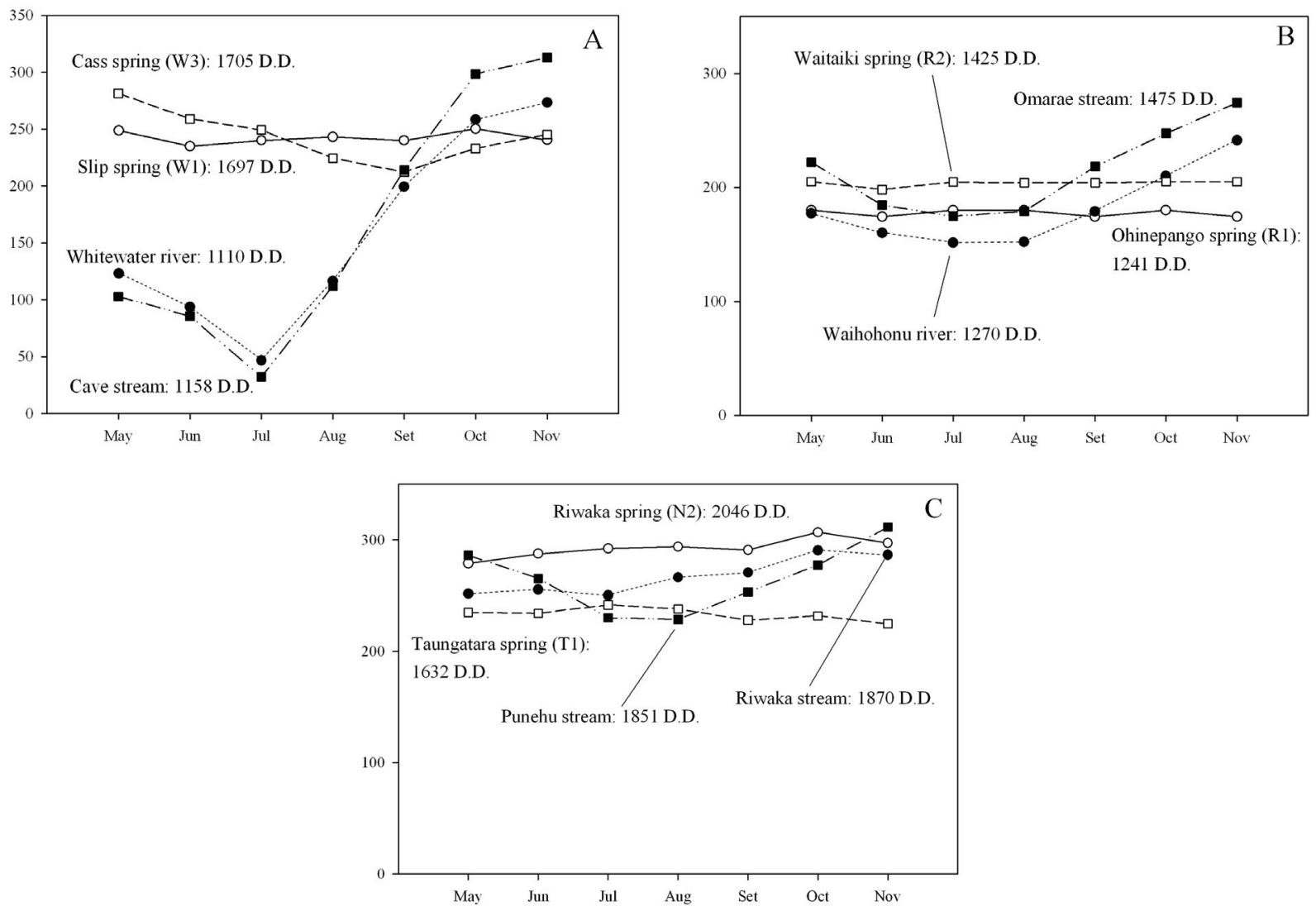

Fig. 1. Distribution of monthly degree-day accumulations for two spring-fed (open symbols) and two run-off-fed (solid symbols) streams in A. Waimakariri basin, B. Ruapehu and C. Nelson and Taranaki, New Zealand, from May to November 2001. Total degree-days (D.D.) accumulated during the seven month period are also given.

The highest and lowest crenic temperature ranges during the seven month period were recorded at Cass and Ohinepango springs (2.5 and $0.1{ }^{\circ} \mathrm{C}$, respectively). Mean monthly thermal amplitude was more than 10 times larger in run-off-fed than spring-fed streams $\left(F_{1.10}\right.$ $=76.32, p<0.0001)$. The number of degree-days accumulated per month was more constant in spring-fed than run-off-fed streams, and in general springs accumulated more, or about as much, heat as nearby run-off-fed streams (Fig. 1). The total number of degree-days, or heat accumulated, during the seven month period was negatively correlated with stream altitude $\left(r_{\mathrm{s}}=-0.72, p\right.$ $<0.01$ ), and crenic thermal amplitude was also negatively correlated with altitude $\left(r_{\mathrm{s}}=-0.76, p<0.01\right)$.

\subsubsection{Longitudinal temperature patterns of spring-fed streams}

Temperature range increased with distance from the source, with the largest daily thermal amplitudes, from April to November 2002, recorded $2 \mathrm{~km}$ from the Taungatara Spring $\left(6.6{ }^{\circ} \mathrm{C}\right)$ and $1 \mathrm{~km}$ from the Taungatara and Waihohonu Spring sources $\left(3.2\right.$ and $3.1{ }^{\circ} \mathrm{C}$, respectively). Mean monthly temperature range was on average 5 times lower at the source than $1 \mathrm{~km}$ downstream, and 8 times lower at the source than $2 \mathrm{~km}$ downstream (Fig. 2). However, the rate of change in mean monthly temperature range varied between springs, for example, at Ohinepango Spring source mean monthly temperature range was similar to that recorded $1 \mathrm{~km}$ from the source (Fig. 2). The number of degree-days accumulated over the 8 month period increased downstream for all springs (Ohinepango Source: 1226; $1 \mathrm{~km}$ : 1477; Taungatara Source: 1856, $1 \mathrm{~km}: 1863,2 \mathrm{~km}$ : 1941; Waitaiki Source: $1625,1 \mathrm{~km}: 1661,2 \mathrm{~km}: 1674)$ except the Waihohonu spring (Source: 1728, $1 \mathrm{~km}$ : 1639).

\subsubsection{Physico-chemical characteristics}

Water temperature ranged from 5.1 to $12.6{ }^{\circ} \mathrm{C}$ at the seven springs and consistently increased downstream for all. Depth (range: 7 - $60 \mathrm{~m}$ ), width (range: 2 - $18 \mathrm{~m}$ ) and flow (range: $0.1-3.6 \mathrm{~m}^{3} \mathrm{~s}^{-1}$ ) tended to increase with distance from the source, while conductivity (range: 40$243 \mu \mathrm{S} \mathrm{cm}^{-1}$ ), nitrate (range: $0.04-0.2 \mathrm{mg} \mathrm{L}^{-1}$ ) and phosphate concentration (range: $0.04-0.6 \mathrm{mg} \mathrm{L}^{-1}$ ) tended to decrease. However, only water velocity significantly increased downstream (Tab. 2). In contrast, $\mathrm{pH}$, which ranged from 6.9 to 8.5 , and oxygen concentration, which ranged from 8.3 to $11.8 \mathrm{mg} \mathrm{mL}^{-1}$, did not exhibit clear downstream changes (Tab. 2). 


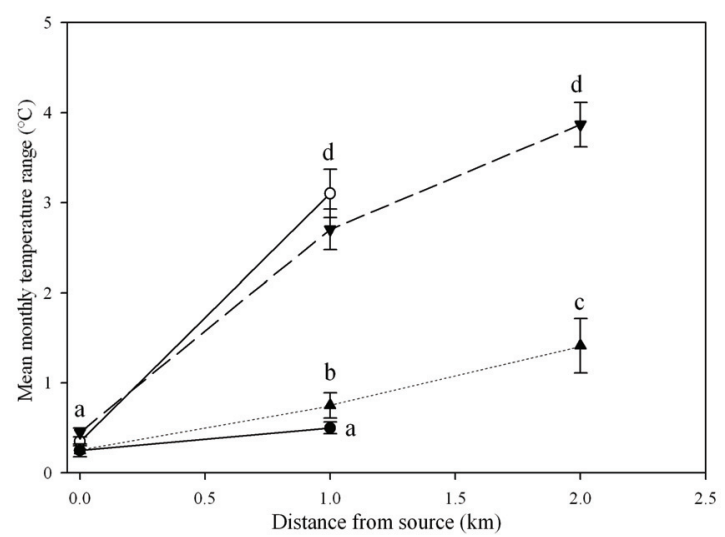

Fig. 2. Variations in the mean $( \pm 1 \mathrm{SE})$ monthly temperature range with distance from source in three spring-fed streams from

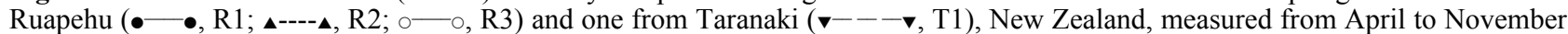
2001. Different letters indicate statistical differences $(p>0,05)$ between mean temperature ranges from the results of a two-way ANOVA (site*distance).

Tab. 2. Physicochemical variables measured at $0 \mathrm{~m}, 100 \mathrm{~m}, 500 \mathrm{~m}$ and $1 \mathrm{~km}$ from the source of seven New Zealand spring-fed streams, in the austral summer of 2001. Mean values and results of one way ANOVA testing for differences in distance from the source and Kendall rank correlation coefficients of physicochemical variables with axis one and three of NMDS are also given $(\mathrm{R} 1=$ Ohinepango spring, $\mathrm{R} 2=$ Waitaiki spring, $\mathrm{T} 1=$ Taungatara spring, N1 = Pearse resurgence, N2 = Riwaka resurgence, W1 = Slip spring, W2 = Hawdon Valley spring, $\mathrm{D}=$ Distance from source, Alt. = Altitude, Temp. $=$ Temperature, Cond. $=$ Conductivity, Vel. = Velocity, Oxy. $=$ Oxygen, Nit. $=$ Nitrates and Phos. $=$ Phosphates. $*=p<0.05)$.

\begin{tabular}{|c|c|c|c|c|c|c|c|c|c|c|c|c|}
\hline Sites & $\begin{array}{c}\mathrm{D} \\
(\mathrm{m})\end{array}$ & $\begin{array}{l}\text { Alt. } \\
\text { (m) }\end{array}$ & $\mathrm{pH}$ & $\begin{array}{l}\text { Temp. } \\
\left({ }^{\circ} \mathrm{C}\right)\end{array}$ & $\begin{array}{l}\text { Cond. } \\
\left(\mu \mathrm{S} \mathrm{cm}^{-1}\right)\end{array}$ & $\begin{array}{l}\text { Flow } \\
\left(\mathrm{m}^{3} \mathrm{~s}^{-1}\right)\end{array}$ & $\begin{array}{l}\text { Depth } \\
\text { (cm) }\end{array}$ & $\begin{array}{l}\text { Vel. } \\
\left(\mathrm{m} \mathrm{s}^{-1}\right)\end{array}$ & $\begin{array}{l}\text { Width } \\
\text { (m) }\end{array}$ & $\begin{array}{c}\text { Oxy. } \\
\left(\mathrm{mg} \mathrm{L}^{-1}\right)\end{array}$ & $\begin{array}{c}\text { Nit. } \\
\left(\mathrm{mg} \mathrm{L}^{-1}\right)\end{array}$ & $\begin{array}{l}\text { Phos. } \\
\left(\mathrm{mg} \mathrm{L}^{-1}\right)\end{array}$ \\
\hline N1 & $\begin{array}{c}0 \\
100 \\
500 \\
1000\end{array}$ & 380 & $\begin{array}{l}8.5 \\
8.4 \\
8.5 \\
8.5\end{array}$ & $\begin{array}{l}7.1 \\
7.2 \\
7.4 \\
7.8\end{array}$ & $\begin{array}{l}180 \\
177 \\
180 \\
179\end{array}$ & $\begin{array}{c}2.22 \\
1.6 \\
3.64 \\
2.35\end{array}$ & $\begin{array}{c}36 \\
36.8 \\
31.6 \\
43\end{array}$ & $\begin{array}{l}0.68 \\
0.59 \\
0.89 \\
0.59\end{array}$ & $\begin{array}{c}12 \\
11.1 \\
18 \\
12\end{array}$ & $\begin{array}{c}10.7 \\
11 \\
11 \\
11\end{array}$ & $\begin{array}{c}0.12 \\
0.1 \\
0.1\end{array}$ & $\begin{array}{l}0.07 \\
0.09 \\
0.06 \\
0.07\end{array}$ \\
\hline $\mathrm{N} 2$ & $\begin{array}{c}0 \\
100 \\
500 \\
1000\end{array}$ & 120 & $\begin{array}{l}8.4 \\
8.5 \\
8.4 \\
8.6\end{array}$ & $\begin{array}{l}10.2 \\
10.4 \\
10.3 \\
12.6\end{array}$ & $\begin{array}{l}243 \\
177 \\
243 \\
170\end{array}$ & $\begin{array}{l}1.84 \\
1.46 \\
1.47 \\
1.17\end{array}$ & $\begin{array}{l}44.8 \\
18.4 \\
24.2 \\
20.4\end{array}$ & $\begin{array}{c}0.77 \\
0.8 \\
0.68 \\
0.82\end{array}$ & $\begin{array}{c}7.3 \\
10.1 \\
11.6 \\
9\end{array}$ & $\begin{array}{l}10.4 \\
10.5 \\
10.7 \\
11.3\end{array}$ & $\begin{array}{c}0.21 \\
0.22 \\
0.22 \\
0.2\end{array}$ & $\begin{array}{l}0.13 \\
0.07 \\
0.05 \\
0.07\end{array}$ \\
\hline W1 & $\begin{array}{c}0 \\
100 \\
500 \\
1000\end{array}$ & 800 & $\begin{array}{l}7.5 \\
7.8 \\
7.9 \\
7.9\end{array}$ & $\begin{array}{l}8.1 \\
8.5 \\
8.4 \\
9.4\end{array}$ & $\begin{array}{c}45.1 \\
62.6 \\
43 \\
40.9\end{array}$ & $\begin{array}{l}0.17 \\
0.18 \\
0.36 \\
0.53\end{array}$ & $\begin{array}{c}13.2 \\
12 \\
20 \\
20.2\end{array}$ & $\begin{array}{l}0.54 \\
0.59 \\
0.62 \\
0.89\end{array}$ & $\begin{array}{l}3.2 \\
2.5 \\
3.7 \\
3.9\end{array}$ & $\begin{array}{c}8.3 \\
9.1 \\
10.2 \\
9.8\end{array}$ & $\begin{array}{c}0.1 \\
0.08 \\
0.08 \\
0.04\end{array}$ & $\begin{array}{l}0.12 \\
0.09 \\
0.12 \\
0.04\end{array}$ \\
\hline W2 & $\begin{array}{c}0 \\
100 \\
500 \\
1000\end{array}$ & 750 & $\begin{array}{l}7.6 \\
7.8 \\
7.8 \\
7.7\end{array}$ & $\begin{array}{c}7.3 \\
7 \\
7.3 \\
8.9\end{array}$ & $\begin{array}{c}51.6 \\
54.3 \\
40.8 \\
58\end{array}$ & $\begin{array}{c}0.03 \\
0.47 \\
1.02 \\
1.5\end{array}$ & $\begin{array}{c}6.6 \\
22 \\
20.4 \\
21.8\end{array}$ & $\begin{array}{l}0.27 \\
0.28 \\
0.64 \\
1.09\end{array}$ & $\begin{array}{c}2 \\
5.6 \\
10.3 \\
8.2\end{array}$ & $\begin{array}{c}9.6 \\
10.3 \\
11 \\
10.7\end{array}$ & $\begin{array}{l}0.06 \\
0.06 \\
0.06 \\
0.05\end{array}$ & $\begin{array}{l}0.11 \\
0.11 \\
0.08 \\
0.09\end{array}$ \\
\hline R1 & $\begin{array}{c}0 \\
100 \\
500 \\
1000\end{array}$ & 1110 & $\begin{array}{l}6.9 \\
7.1 \\
7.4 \\
7.5\end{array}$ & $\begin{array}{l}5.7 \\
6.1 \\
6.1 \\
5.1\end{array}$ & $\begin{array}{l}37 \\
65 \\
49 \\
65\end{array}$ & $\begin{array}{c}0.07 \\
1.62 \\
1.5 \\
2.65\end{array}$ & $\begin{array}{c}13.4 \\
31.2 \\
42.4 \\
59.25\end{array}$ & $\begin{array}{l}0.33 \\
0.53 \\
0.79 \\
0.83\end{array}$ & $\begin{array}{c}1.8 \\
9.7 \\
5.6 \\
9\end{array}$ & $\begin{array}{l}10.5 \\
10.7 \\
11.5 \\
11.2\end{array}$ & $\begin{array}{c}0.07 \\
0.1 \\
0.04 \\
0.11\end{array}$ & $\begin{array}{l}0.16 \\
0.31 \\
0.18 \\
0.17\end{array}$ \\
\hline $\mathrm{R} 2$ & $\begin{array}{c}0 \\
100 \\
500 \\
1000\end{array}$ & 800 & $\begin{array}{c}7.7 \\
8.2 \\
8 \\
7.7\end{array}$ & $\begin{array}{c}6.8 \\
6.6 \\
7 \\
7\end{array}$ & $\begin{array}{c}76 \\
104 \\
105 \\
78\end{array}$ & $\begin{array}{c}0.31 \\
0.4 \\
0.25 \\
0.52\end{array}$ & $\begin{array}{c}23.1 \\
19.8 \\
12.18 \\
27.66\end{array}$ & $\begin{array}{c}0.1 \\
0.48 \\
0.9 \\
0.3\end{array}$ & $\begin{array}{l}18 \\
5.5 \\
3.1 \\
7.8\end{array}$ & $\begin{array}{l}10.9 \\
11.7 \\
11.8 \\
11.6\end{array}$ & $\begin{array}{l}0.07 \\
0.13 \\
0.07 \\
0.07\end{array}$ & $\begin{array}{c}0.29 \\
0.45 \\
0.31 \\
0.3\end{array}$ \\
\hline $\mathrm{T} 1$ & $\begin{array}{c}0 \\
100 \\
500 \\
1000\end{array}$ & 560 & $\begin{array}{l}7.8 \\
7.8 \\
7.8 \\
7.8\end{array}$ & $\begin{array}{l}7.7 \\
7.8 \\
8.4 \\
9.2\end{array}$ & $\begin{array}{c}112 \\
109 \\
109 \\
81\end{array}$ & $\begin{array}{l}0.43 \\
0.16 \\
0.14 \\
0.37\end{array}$ & $\begin{array}{l}25.2 \\
14.2 \\
17.4 \\
19.2\end{array}$ & $\begin{array}{l}0.22 \\
0.43 \\
0.34 \\
0.52\end{array}$ & $\begin{array}{c}9 \\
3.2 \\
2.6 \\
5.2\end{array}$ & $\begin{array}{l}10.2 \\
10.5 \\
10.4 \\
10.2\end{array}$ & $\begin{array}{c}0.16 \\
0.12 \\
0.1 \\
0.09\end{array}$ & $\begin{array}{l}0.55 \\
0.57 \\
0.58 \\
0.61\end{array}$ \\
\hline Average & $\begin{array}{c}0 \\
100 \\
500 \\
1000\end{array}$ & & $\begin{array}{l}7.8 \\
7.9 \\
8.0 \\
8.0\end{array}$ & $\begin{array}{l}7.6 \\
7.7 \\
7.8 \\
8.6\end{array}$ & $\begin{array}{c}106.4 \\
107.0 \\
110.0 \\
96.0\end{array}$ & $\begin{array}{l}0.72 \\
0.84 \\
1.20 \\
1.30\end{array}$ & $\begin{array}{l}23.19 \\
22.06 \\
24.03 \\
30.22\end{array}$ & $\begin{array}{l}0.42 \\
0.53 \\
0.69 \\
0.72\end{array}$ & $\begin{array}{l}7.6 \\
6.8 \\
7.8 \\
7.9\end{array}$ & $\begin{array}{l}10.1 \\
10.5 \\
10.9 \\
10.8\end{array}$ & $\begin{array}{l}0.11 \\
0.12 \\
0.10 \\
0.09\end{array}$ & $\begin{array}{l}0.20 \\
0.24 \\
0.20 \\
0.19\end{array}$ \\
\hline $\begin{array}{c}\text { F3,24 } \\
\text { Axis one } \\
\text { Axis three }\end{array}$ & $\begin{array}{c}0.08 \\
-0.39 *\end{array}$ & & $\begin{array}{c}0.29 \\
0.09 \\
-0.44^{*}\end{array}$ & $\begin{array}{c}0.52 \\
-0.05 \\
-0.44^{*}\end{array}$ & $\begin{array}{c}0.07 \\
0.32 \\
-0.29\end{array}$ & $\begin{array}{c}1.4 \\
0.07 \\
-0.13\end{array}$ & $\begin{array}{l}0.67 \\
0.16 \\
0.00\end{array}$ & $\begin{array}{l}2.87 * \\
-0.01 \\
-0.19\end{array}$ & $\begin{array}{c}0.08 \\
-0.04 \\
-0.06\end{array}$ & $\begin{array}{l}1.93 \\
0.21 \\
0.03\end{array}$ & $\begin{array}{c}0.54 \\
0.26 \\
-0.03\end{array}$ & $\begin{array}{c}0.2 \\
0.35^{*} \\
0.18\end{array}$ \\
\hline
\end{tabular}


Tab. 3. Results of two way ANOVA testing for differences in site and distance from the source for invertebrate community parameters and resource levels measured at $0 \mathrm{~m}(1), 100 \mathrm{~m} \mathrm{(2),500} \mathrm{m} \mathrm{(3)} \mathrm{and} 1 \mathrm{~km}$ (4) from the source of seven New Zealand spring-fed streams, in the austral summer of 2001. Kendall rank correlation coefficients of level of resources with axis one and three of NMDS are also given $(\mathrm{R} 1=$ Ohinepango spring, R2 = Waitaiki spring, T1 = Taungatara spring, N1 = Pearse resurgence, N2 = Riwaka resurgence, $\mathrm{W} 1=$ Slip spring, $\mathrm{W} 2=$ Hawdon Valley spring; $*=p 0.05-0.01, * *=p<0.01$ ).

\begin{tabular}{|c|c|c|c|c|c|c|c|}
\hline & $\begin{array}{l}\text { Site } \\
F_{6.55} \\
\end{array}$ & Tukey's & $\begin{array}{c}\text { Distance } \\
F_{3.55} \\
\end{array}$ & Tukey's & $\begin{array}{c}\text { Interaction } \\
F_{18.55} \\
\end{array}$ & Axis 1 & Axis 3 \\
\hline CPOM & $8.6^{* *}$ & 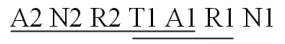 & $19.61^{* *}$ & $\underline{132} 4$ & $5.71 * *$ & 0.02 & 0.07 \\
\hline FPOM & 1.86 & & $18.76^{* *}$ & $1 \underline{23} 4$ & 1.45 & -0.01 & 0.31 \\
\hline Chlorophyll- $a$ & $6.08 * *$ & $\underline{\mathrm{N} 2 \mathrm{R} 2 \mathrm{~A} 1 \mathrm{~N} 1 \mathrm{~T} 1 \mathrm{~A} 2} \mathrm{R} 1$ & 2.06 & & 1.24 & 0.02 & -0.02 \\
\hline Number of Taxa & $12.83^{* *}$ & N2 A1 A2 T1 N1 R2 R1 & $10.5^{* *}$ & $\underline{4321}$ & $3.06 * *$ & & \\
\hline Number of Individuals & $14.31^{* *}$ & A1 A2 N2 N1 R1 R2 T1 & 1.32 & & $4.68 * *$ & & \\
\hline Rarified Number of Taxa & $28.17^{* * *}$ & $\mathrm{~T} 1 \mathrm{~N} 2 \mathrm{R} 2 \mathrm{~A} 2 \mathrm{~N} 1 \overline{\mathrm{A} 1 \mathrm{R} 1}$ & $22.12^{\text {*** }}$ & $\underline{432} 1$ & $1.8^{*}$ & & \\
\hline Shannon Diversity Index & $22.66 * *$ & T1 N2 R2 A2 N1 A1 R1 & $19.02 * *$ & $\underline{342} 1$ & $2.1^{*}$ & & \\
\hline
\end{tabular}

Conductivity was higher in springs of the Nelson region, while phosphate concentration was higher in the Ruapehu and Taranaki springs (Tab. 2). Ohinepango Spring and Pearse and Riwaka Resurgence were the springs with the largest flows, followed by Hawdon Valley Spring, while the Waitaiki, Taungatara and Slip springs had the lowest flows (Tab. 2).

\subsection{Periphyton, organic matter}

Total periphyton biomass did not change substantially downstream from the sources (Tab. 3), however, pigment concentration was lower $1 \mathrm{~km}$ from the source than at any other sampling site in 5 of the sampled springs (R1, R2, T1, W1 and W2; Tab. 3). Periphyton biomass was lower in the Ohinepango Spring (R1) and higher in Riwaka Resurgence (N2; Tab. 3). On average, concentrations of coarse and fine organic matter were more than 4 times higher at sources than $1 \mathrm{~km}$ downstream (Tab. 3). Pearse Resurgence had the lowest concentration of CPOM (Tab. 3).

\subsection{Invertebrate abundance and diversity patterns}

A total of 79 insect and 10 non-insect taxa were collected from the springs and their associated springfed streams. Pooling the samples from sources and spring-fed streams for each site, the number of invertebrate taxa recorded was highest at Slip spring (52), followed by Riwaka Resurgence (51), Hawdon Valley Spring (50), Waitaiki Spring (46), Taungatara Spring (45) and Pearse Resurgence (44). In contrast, only 31 taxa were collected from Ohinepango Spring and its spring-fed stream. Overall, the number of invertebrate taxa, pooled for each distance, and the mean number of taxa per Surber sample increased with distance from the source (Fig. 3, Tab. 3), however, when looking at each spring independently, changes were only significant for Riwaka Resurgence and Taungatara Spring (Tab. 4). Most springs showed a downstream decrease in the number of individuals, although it was only significant for Slip and Waitaiki Springs (Fig. 3, Tab. 4). Rarified number of species and evenness increased with distance from the source in all springs (Fig. 3, Tab. 3), although differences were only marked between $500 \mathrm{~m}$ and $1 \mathrm{~km}$ from the source in Hawdon Valley and Waitaiki Springs (Tab. 4). In Ohinepango, Taungatara and Waitaiki Springs the downstream increase in total number of taxa was positively correlated with the number of degreedays and the monthly temperature range $\left(r_{\mathrm{s}}=0.8\right.$ in both cases, $p<0.001$ ).

\subsection{Community structure}

\subsubsection{Taxonomic composition}

Insect taxa dominated at all sources, comprising 60 to $98 \%$ of the total number of animals in the community, except at the Waitaiki and Hawdon valley sources, where Oligochaeta and Potamopyrgus antipodarum, and Oligochaeta, Paraleptamphopus subterraneus and Nematoda, comprised 74 and $53 \%$ of the invertebrate communities, respectively. Overall, the density of noninsect taxa was 15 times higher at the two upstream locations compared with the two further downstream $\left(F_{3.55}=39, p<0.0001\right)$; Nematoda, $P$. antipodarum, Oligochaeta, $P$. subterraneus and Paracalliope fluviatilis contributed $30 \%$ of the invertebrate community in the sources (Tab. 5). Coleoptera and Ephemeroptera densities were more than 5 times higher at $1 \mathrm{~km}$ than at the source $\left(F_{3.55}=14.5\right.$ and 81.6, respectively, $\left.p<0.0001\right)$. Hydora sp. and Hydraenidae beetles increased in density downstream (in R1, T1, W2, N1 and N2), contributing more than $5 \%$ of the invertebrate community $1 \mathrm{~km}$ from the source. The mayfly Deleatidium spp. increased in numbers downstream in all springs, accounting for less than $2 \%$ at the sources to more than $27 \%$ of the total invertebrate community $1 \mathrm{~km}$ from the source (Tab. 5). Austroclima spp. (in $\mathrm{T} 1, \mathrm{~N} 2$ and R2) and Coloburiscus humeralis (in T1 and W2) also contributed to the downstream increase in mayfly densities (Tab. 5). 

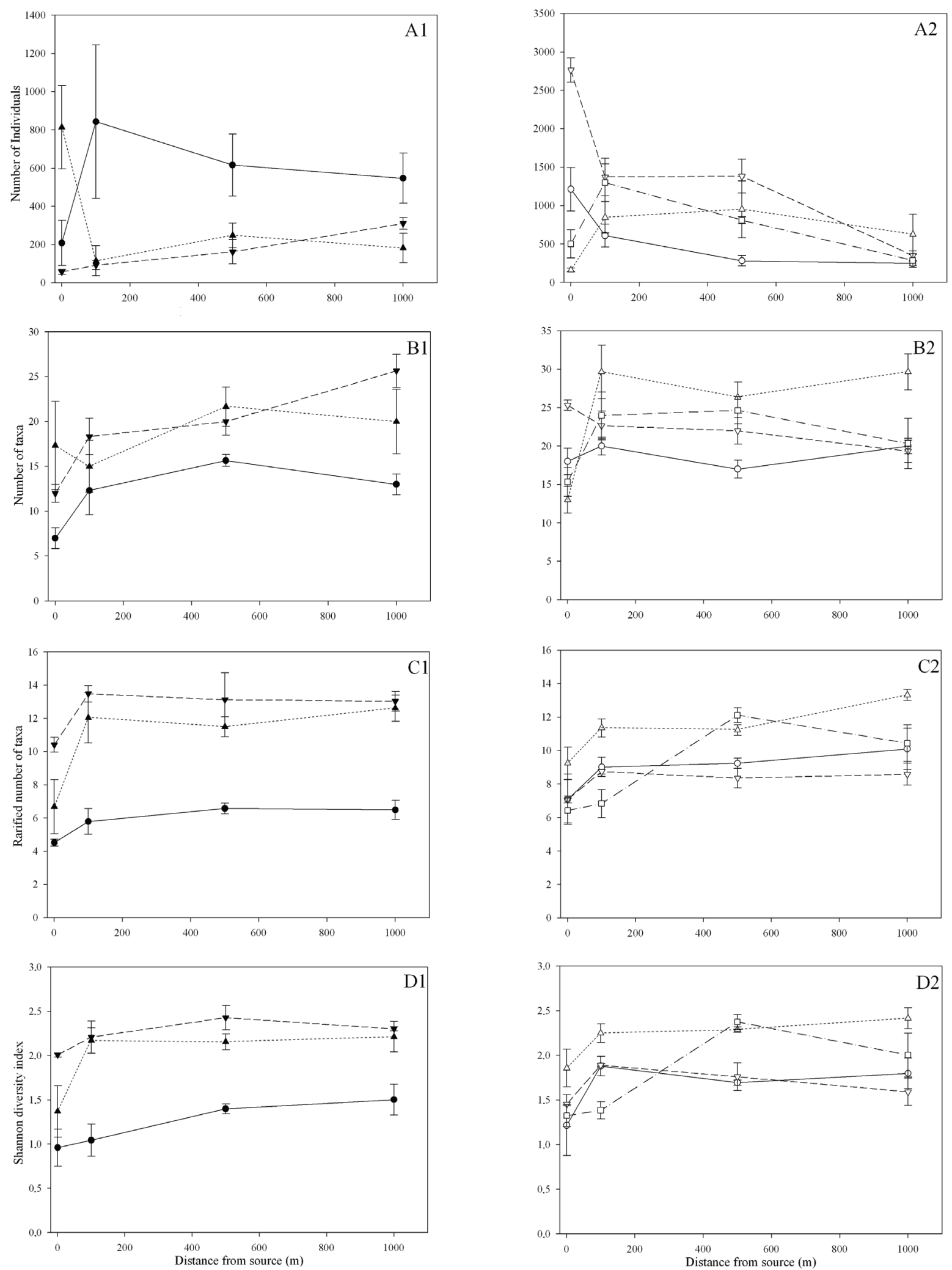

Fig. 3. Mean ( \pm 1 SE) A. Number of Individuals, B. Number of Taxa, C. Number of rarified taxa and D. Shannon diversity index for invertebrate communities collected in seven spring-fed streams in New Zealand, in the austral summer of 2002 (1 for North Island springs, $\bullet-\bullet, \mathrm{R} 1 ; \boldsymbol{\Delta}---\mathbf{\Delta}, \mathrm{R} 2 ; \boldsymbol{\nabla}---\boldsymbol{\nabla}, \mathrm{T} 1 ; 2$ for South Island springs, $\nabla---\nabla, \mathrm{W} 1 ; \square--\cdot \square, \mathrm{W} 2 ; \bigcirc-\bigcirc, \mathrm{N} 1 ; \triangle---\triangle, \mathrm{N} 2)$. 
Tab. 4. Tukey's post-hoc tests for the interaction between site and distance from the source given by the two way ANOVA for invertebrate community parameters measured at $0 \mathrm{~m}$ (1), $100 \mathrm{~m} \mathrm{(2),} 500 \mathrm{~m} \mathrm{(3)}$ and $1 \mathrm{~km}(4)$ from the source of seven New Zealand spring-fed streams, in the austral summer of 2001 (n.s. $=P>0.05$, lines join distances with no statistical differences; Taxa $=$ Number of taxa; Rarified Taxa $=$ Rarified number of taxa; Individuals $=$ Number of individuals; Shanon $=$ Shannon diversity index).

\begin{tabular}{|c|c|c|c|c|}
\hline Spring site & Taxa & Rarified Taxa & Individuals & Shannon \\
\hline Ohinepango (R1) & n.s. & n.s. & n.s. & n.s. \\
\hline Waitaiki (R2) & n.s. & $4 \underline{231}$ & $\underline{1342}$ & $\underline{4231}$ \\
\hline Taungatara (T1) & $\underline{4321}$ & n.s. & n.s. & n.s. \\
\hline Slip (W1) & n.s. & n.s. & $\underline{1324}$ & n.s. \\
\hline Hawdon Valley (W2) & n.s. & 3421 & n.s. & 3421 \\
\hline Pearse (N1) & n.s. & n.s. & n.s. & n.s. \\
\hline Riwaka (N2) & $4 \underline{231}$ & n.s. & n.s. & n.s. \\
\hline
\end{tabular}

Trichoptera were 5 times less abundant at the sources than at any other distance $\left(F_{3.55}=3.6\right.$ and 16.4 , respectively, $p<0.0001$; Tab. 5). The cased caddisflies Pycnocentria spp. (in R2, T1, W1, W2 and N2) and Zelolessica spp. (in R1, R2, T1, W2, N1 and N2) reached their highest densities 100 and $500 \mathrm{~m}$ from the sources, whereas Beraeoptera roria, Olinga feredayi and Pycnocentrodes spp., were in greater abundance 1 $\mathrm{km}$ from the sources (in $\mathrm{T} 1, \mathrm{~W} 1, \mathrm{~W} 2$ and $\mathrm{N} 2$ ), where they contributed more than $13 \%$ of the overall invertebrate community (Tab. 5). Densities of Diptera were 3 times higher at the two upstream locations compared with the two further downstream $\left(F_{3.55}=3.6, p<0.001\right)$. Chironomids reached maximum densities at 0 (in R2, $\mathrm{T} 1, \mathrm{~W} 1, \mathrm{~W} 2$ and N1) and $100 \mathrm{~m}$ (in R2 and N2). They decreased in relative abundance from $58 \%$ at the sources to $27 \%$ at $1 \mathrm{~km}$.

Coleoptera, Ephemeroptera and Trichoptera richness increased with distance from the source $\left(F_{3.55}=19.6\right.$, 38.9 and 11.7 respectively, $p<0.001$ ), while the number of non-insect taxa was higher at the sources $\left(F_{3.55}=\right.$ 13.1, $p<0.001)$. Diptera and Plecoptera did not show any differences in diversity with distance downstream $\left(F_{3.55}=1.9\right.$ and 2.3 respectively, $\left.p>0.05\right)$. ANOSIM indicated that invertebrate communities from sources were significantly different to any of those found downstream $\left(R_{0-100}=0.103, R_{0-500}=0.171, R_{0-1.000}=0.369\right.$, all of them $p<0.01$ ), and invertebrate communities found $100 \mathrm{~m}$ from the source were also significantly different to those found at $1 \mathrm{~km}\left(R_{100-1.000}=0.131, p<0.01\right)$, although $R$ values were not high. Invertebrate communities of the spring-fed streams were more similar to each other $1 \mathrm{~km}$ from the source (Bray-Curtis average similarity $=40.2)$ and most dissimilar at the sources (Bray-Curtis average similarity $=27.01$ ).

Final stress for the NMDS analysis was 12.93, indicating a reliable ordination (McCune \& Mefford 1995). Axis 1 and 2 explained $28.8 \%$ and $28.7 \%$ of the total variance, respectively. Source and $100 \mathrm{~m}$ locations fell in the upper part of the ordination, except for $500 \mathrm{~m}$ and $1 \mathrm{~km}$ sites at the Ohinepango Spring source (R1), whereas $500 \mathrm{~m}$ and $1 \mathrm{~km}$ sites fell at the bottom, except for the Riwaka resurgence source (R2) and the $100 \mathrm{~m}$ site from Taungatara Spring (T1; Fig. 4). Moreover, North Island sites ( $\mathrm{R}$ and $\mathrm{T}$ sites) lay towards the right of the ordination, while sites from the South Island (N and $\mathrm{W}$ ) were to the left. Axis 1 was positively correlated to phosphate concentration, whereas axis 3 was positively correlated to FPOM concentration and negatively to temperature, $\mathrm{pH}$ and distance from the source (Tab. 2). Densities of Hydrobiosidae (early instars), Muscidae, Naonella forsythia, Oeconesus sp., Oligochaeta, Ostracoda, Oxyethira albiceps, Olinga feredayi, Paraleptamphopus subterraneus and Pycnocentria hawdoniana increased in sites towards the left of the ordination, while the densities of Orthopsyche sp., Pycnocentria funerea, Zelandoperla decorata and Zelandobius confusus decreased in the same direction. The densities of Maoridiamesa spp. and Limonia sp. increased along axis 3, while Coloburiscus humeralis, Cryptobiosella sp., Eriopterini, Hydraenidae and Zelandobius confusus decreased in that direction.

\subsubsection{Functional feeding group composition}

The relative abundance of sessile browsers (SB) decreased progressively from the sources, whereas mobile browsers (MB) increased (Tab. 5). Filterers also increased in relative abundance downstream from the sources, principally as a result of the increased densities of Austrosimulium spp., C. humeralis and Hydropsychidae caddisflies (Tab. 5). Predator densities were similar at all distances from the sources, but shredders had lower relative abundances at the sources compared to downstream locations (Tab. 5).

\section{DISCUSSION}

\subsection{Thermal patterns}

Temperature variation was much larger in run-offfed than spring-fed streams. As in other New Zealand streams (Johnson 1971; Fowles 1975; Grant 1977), minimum temperatures occurred in June-July. Other studies on New Zealand (Michaelis 1976; Cowie \& Winterbourn 1979) and overseas (Ferrington 1995b; Botosaneanu 1998) springs have shown that crenic temperatures closely reflect the mean annual air temperature of the surrounding region. In this study, mean temperatures for Slip and Cass springs $\left(8\right.$ and $\left.8.2{ }^{\circ} \mathrm{C}\right)$ and Riwaka Resurgence $\left(10^{\circ} \mathrm{C}\right)$ over the study period were close to the mean annual temperatures for Waimakariri $\left(8.6^{\circ} \mathrm{C}\right)$ and Nelson $\left(11.8^{\circ} \mathrm{C}\right)$, respectively. The correlation between altitude and heat accumulated over the sevenmonth period is also related to the interaction between air and water temperatures (Smith \& Lavis 1975; Crisp \& Howson 1982; Stefan \& Preud'homme 1993).

Thermal range increased with distance from the source in all spring-fed streams, although the rate of increase with distance varied between springs (Fig. 2). 


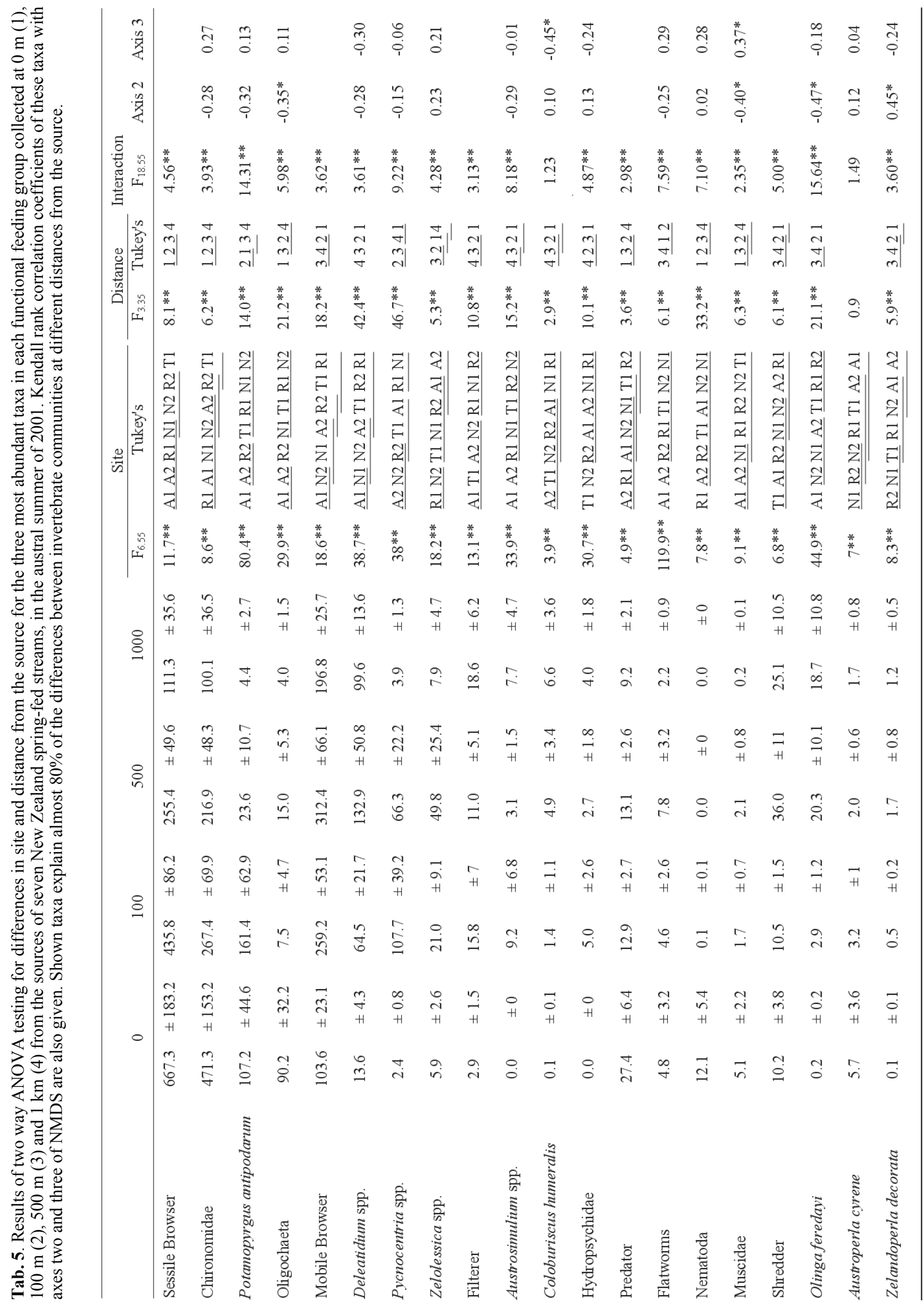




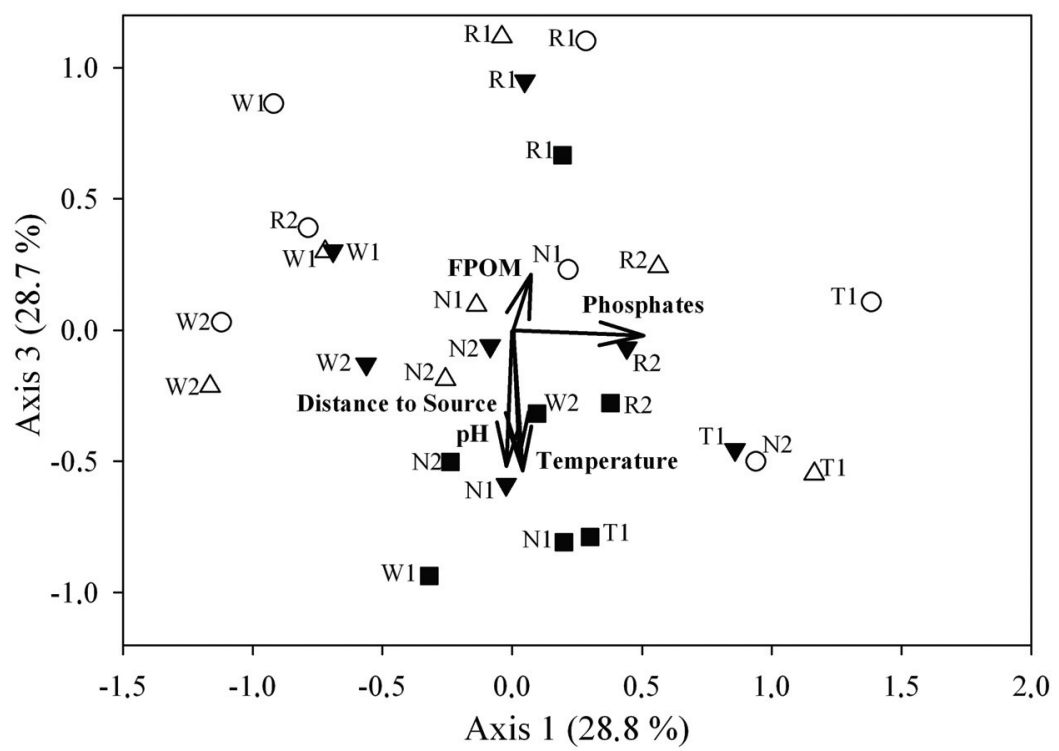

Fig. 4. Nonmetric multidimensional scaling (NMDS) plot of axis-1 against axis-3 for mean macroinvertebrate communities collected in New Zealand springs and springbrooks at different distances from the source (source: $\bigcirc$, at $100 \mathrm{~m}: \triangle$, at $500 \mathrm{~m}: \mathbf{\nabla}$ and at $1000 \mathrm{~m}$ : च). Regions are denoted as Waimakariri: W, Nelson: N, Ruapehu: R and Taranaki: T.

This is extremely important for the delineation of the eucrenal zone because the boundary between a springhead and its spring-fed stream has usually been established as where the temperature differs $>2{ }^{\circ} \mathrm{C}$ from the temperature at the source (Erman \& Erman 1995; Smith 2002; Fumetti et al. 2007). This criterion would give extremely large eucrenal areas for the springs considered in this study, and for any other large springs (Barquín \& Death 2004). Other studies have reported increases in thermal amplitude of between $3{ }^{\circ} \mathrm{C}, 10{ }^{\circ} \mathrm{C}$ and $20{ }^{\circ} \mathrm{C}$ approximately $1 \mathrm{~km}$ downstream from sources (Sloan 1956; Minshall 1968; Meffe \& Marsh 1983), however, little has been said about the factors that cause longitudinal differences in thermal amplitude within springs (but see Barquín \& Death 2009). The type of aquifer feeding the spring (shallow or deep; Bonacci 1987; Aquilina et al. 2006), the volume of crenic discharge, the difference between water and surrounding air temperatures (i.e., due to altitude), and the type (spring-, run-off-, snow- or glacier-fed streams) and number of tributaries that enter the spring-fed stream, could all be important factors that might determine the degree of temperature variation as one moves downstream from sources (Ward 1985). In this study, altitude is a good predictor of thermal amplitude between sources, but we cannot account for the effect of aquifer type. However, mean monthly amplitude was more than $1.2{ }^{\circ} \mathrm{C}$ for all the springs, which could be associated with deep regional aquifers (Bonacci 1987; Erman \& Erman 1995; Aquilina et al. 2006). With respect to the volume of crenic discharge and the number and type of tributaries, Taungatara and Ohinepango spring-fed streams had no tributaries entering along their studied lengths, although Ohinepango Spring had a much higher flow $\left(1.6 \mathrm{~m}^{3} \mathrm{~s}^{-1}\right.$ at $\left.100 \mathrm{~m}\right)$ than Taungatara Spring $\left(0.2 \mathrm{~m}^{3} \mathrm{~s}^{-1}\right.$ at $\left.100 \mathrm{~m}\right)$. Consequently, mean monthly thermal amplitude was zero $1 \mathrm{~km}$ from the source of the Ohinepango Spring, but had increased by more than $2{ }^{\circ} \mathrm{C}$ in the Taungatara Spring. On the other hand, Waitaiki Spring had a comparable flow $\left(0.4 \mathrm{~m}^{3} \mathrm{~s}^{-1}\right.$ at $100 \mathrm{~m}$ ) to Taungatara Spring, although a large spring joined this stream above the $1 \mathrm{~km}$ sampling site, and another above the $2 \mathrm{~km}$ point (Pers. Obs.). It is possible that these may have reduced the rate of increase in temperature range in the Waitaiki spring-fed stream. Thus, the results from the present study seem to support the influence of altitude, discharge and number and type of tributaries determining the rate of change in thermal amplitude as one moves downstream from sources, although more detailed studies need to be done to clarify the role of each of these factors.

\subsection{Spring/spring-fed stream environmental gradient}

Food resources (i.e., periphyton biomass) and physicochemical parameters did not vary markedly along the length of the spring-fed streams, apart from the increase in temperature and water velocity, and the decrease in organic matter away from the source. This is consistent with the findings of other studies, which reported increased water velocities (Minshall 1968), slight increases in $\mathrm{pH}$ and dissolved oxygen (Davidson \& Wilding 1943; Sloan 1956) and a reduction in nitrates (Ward \& Dufford 1979) with distance from the source. The increase in downstream water velocity may explain the decrease in organic matter, as the transport capacity of the current is enhanced by higher velocities. Also, some run-off-fed tributaries joined the spring-fed stream channel in the first few kilometres from Slip and 
Hawdon Valley springs, increasing the instability of the stream bed and thus reducing the amount of organic matter. However, the periphyton communities did not seem to reflect this decrease in stability.

\subsection{Longitudinal changes on invertebrate communities}

Invertebrate communities at sources differed more from each other than invertebrate communities $1 \mathrm{~km}$ from the source. The change in relative abundance between sessile browsers and motile browsers may be related to the increased variability in flow downstream. Chironomids and non-insect taxa were abundant at the sources, whereas chironomids, Pycnocentria spp. and Zelolessica spp. were abundant at middle distances from the sources. All these taxa are known to be negatively affected by flow disturbance (Barquín \& Death 2006). Finally, invertebrate assemblages $1 \mathrm{~km}$ from the source accumulated more taxa that are common to run-off-fed streams, for example Hydropsychidae, Pycnocentrodes spp., B. roria, $O$. feredayi, elmid beetles, and the mayflies Deleatidium spp. and C. humeralis (Death \& Winterbourn 1995; Winterbourn 1997). The greater similarities between the invertebrate communities at $1 \mathrm{~km}$ from the source may therefore be a direct consequence of the higher frequency of disturbance, which can limit the invertebrate fauna. Barquín \& Death (2006) also found invertebrate communities from run-off-fed streams to be more similar to each other than invertebrate communities from spring-fed streams. Springs that lack invertebrate drift, and thus, can only be colonized by upstream movements, hyporheic or aerial sources, may also be considered more isolated habitats than runoff-fed streams. The higher degree of isolation may confer greater local variability to the invertebrate communities in spring-fed streams. Moreover, drift may also be responsible for taxon accumulation as one moves downstream, although we do not have data to support this hypothesis.

Changes in periphyton biomass, organic matter and physicochemical parameters did not seem to parallel the downstream changes in the invertebrate fauna. Invertebrate richness, rarified number of taxa and evenness all increased downstream, and were positively correlated with an increase in temperature amplitude. Moreover, invertebrate communities at different distances from the R1 source did not seem to differ much, R1 being the spring with higher flows and higher thermal constancy. Thus water temperature range seems to play an important role in determining longitudinal changes in macroinvertebrate communities. However, correlation does not equate with causation and, in almost every stream, the increase in the number of taxa was greater from the source to $100 \mathrm{~m}$ compared with that from $100 \mathrm{~m}$ to $1 \mathrm{~km}$ (Fig. 4, Tabs 2 and 3). This indicates that patterns in invertebrate richness cannot be simply explained by an increase in temperature amplitude, as changes in thermal amplitude from the source to $100 \mathrm{~m}$ are much smaller than those from $100 \mathrm{~m}$ to $1 \mathrm{~km}$, and other factors might also be at work.

Minshall (1968) attributed the spatial patterns of the invertebrate fauna of a woodland spring-fed stream in Kentucky to changes in thermal amplitude, flow and substratum composition. The lack of substratum composition data in this study prevents us from accounting for the effect of this variable on longitudinal changes in invertebrate communities. However, we observed that exposed bedrock and boulders dominate in the Pearse and Riwaka resurgences compared to downstream reaches, whereas the Hawdon Valley, Ohinepango, Waitaiki and Taungatara springs were dominated more by sand, silt and mud at their origins than at downstream locations (Pers. Obs.). The dominant substratum changed rapidly as we moved downstream, especially in those sources dominated by finer sediments (Pers. Obs.). Thus, substratum may play an important role in determining the differences between invertebrate communities at the source and immediately downstream (i.e., at $100 \mathrm{~m}$ sites). The larger proportion of non-insect taxa, especially Oligochaeta and Nematoda, at the Hawdon Valley, Ohinepango and Waitaiki sources could be attributed to the preference of these taxa for soft substrata (Hynes 1970; Minshall 1984; Allan 1996). Furthermore, the lack of animals and organic matter drifting in the first few metres of the spring is another factor that may increase the differences in invertebrate communities between sources and $100 \mathrm{~m}$ sites (Barquín \& Death 2004). Lack of organic matter in the flowing water may also explain the relative paucity of filter feeders in the sources. Thus, accounting for the effect of substratum composition and drifting organisms and organic matter may be necessary to clarify invertebrate community longitudinal changes along crenal biotopes.

\section{CONCLUSIONS}

Temperature amplitude was lower in the springs than in the run-off-fed streams. Thermal amplitude increased downstream from the sources, probably at a rate influenced by flow, altitude and number and type of tributaries entering the spring-fed stream. Longitudinal changes in the number of invertebrate taxa and evenness were positively correlated with an increase in temperature amplitude, however, other factors such as substratum composition, stability and invertebrate drift may also play an important role in the determination of longitudinal changes in invertebrate community composition and structure along spring-fed streams.

\section{ACKNOWLEDGEMENTS}

We are grateful to Kirsty Francis and the postgraduate students in the Ecology Department, Massey University, for assistance in the field and in the lab. We are also thankful to Pablo Barquín, Lucía Creste, and Kyrin Weaver for help with bug sorting, and to Fiona Death for editing the manuscript. We would also like to thank 
to two anonymous reviewers for comments that greatly improved the paper. This research was supported by a scholarship from the Department of Education, Universities and Research of the Basque Government.

\section{REFERENCES}

Allan, J.D. 1996. Stream ecology; Structure and Function of Running Waters. Chapman \& Hall: 388 pp.

Aquilina, L., B. Ladouche \& N. Dörfliger. 2006. Water storage and transfer in the epikarst of karstic systems during high flow periods. J. Hydrol., 327: 472-485.

Barquín, J. \& R.G. Death. 2004. Patterns of invertebrate diversity in streams and freshwater springs in Northern Spain. Arch. Hydrobiol., 161: 329-349.

Barquín, J. \& R.G. Death. 2006. Spatial patterns of macroinvertebrate diversity in New Zealand springbrooks and rithral streams. J. N. Am. Benthol. Soc., 25(4): 768-786.

Barquín, J. \& R.G. Death. 2009. Physico-chemical differences in karst springs of Cantabria, northern Spain: Do invertebrate communities correspond?. DOI 10.1007/s10452008-9170-2. Aquat. Ecol., 43: 445-455.

Bonacci, O. 1987. Karst Springs. In: Douglas, I. and M. Marcus (Eds), Karst Hydrology; with special reference to the Dinaric karst. Springer-Verlag, Berlin: 49-102.

Botosaneanu, L. 1998. Studies in Crenobiology; The biology of springs and springbrooks. Backhuys Publishers, Leiden: $261 \mathrm{pp}$.

Clarke, K.R. \& R.M. Warwick. 1994. Change in marine communities: an approach to statistical analysis and interpretation. Plymouth Marine Laboratory, Natural Environment Research Council, Plymouth, UK: 144 pp.

Cowie, B. 1990. Community dynamics of the benthic fauna in a West Coast stream ecosystem. PhD thesis Thesis, University of Canterbury, Christchurch.

Cowie, B. \& M.J. Winterbourn. 1979. Biota of a subalpine springbrook in the Southern Alps. N. Z. J. Mar. Freshwat. Res., 13(2): 295-301.

Crisp, D.T. \& G. Howson. 1982. Effect of air temperature upon mean water temperature in streams in the north Pennines and English Lake district. Freshwat. Biol., 12: 359367.

Danks, H.V. \& D.D. Williams. 1991. Arthropods of springs, with particular reference to Canada: synthesis and needs for research. Mem. Ent. Soc. Can., 155: 203-217.

Davidson, F.A. \& J.L. Wilding. 1943. A quantitative faunal investigation of a cold spring community. Am. Midl. Nat., 29: 200-209.

Death, R.G. 1995. Spatial patterns in benthic invertebrate community structure: products of habitat stability or are they habitat specific? Freshwat. Biol., 33: 455-467.

Death, R.G. \& M.J. Winterbourn. 1995. Diversity patterns in stream benthic invertebrate communities: the influence of habitat stability. Ecology, 76(5): 1446-1460.

Erman, N.A. \& D.C. Erman. 1992. Factors determining biodiversity in Sierra Nevada cold spring systems. In: Hall, C.A., V. Doyle-Jones and B. Widawski (Eds), The history of water: Eastern Sierra Nevada, Owens valley, WhiteInyo mountains. University of California, Los Angeles: 119-127.

Erman, N.A. \& D.C. Erman. 1995. Spring permanence, Trichoptera species richness, and the role of drought. $J$. Kans. Entomol. Soc., 68(2): 50-64.

Ferrington, J.L.C. 1995a. Biodiversity of aquatic insects and other invertebrates in springs. J. Kans. Entomol. Soc., 68: 165 pp.

Ferrington, L.C. 1995b. Biodiversity of aquatic insects and other invertebrates in springs: introduction. J. Kans. Entomol. Soc., 68(2): 1-3.

Fisher, S.G. 1982. Succession in streams. In: Barnes, J.R. and G.W. Minshall (Eds), Stream Ecology; Application and testing of general ecological theory. Plenum Press, New York: 7-28.

Fowles, C.R. 1975. Temperature records from a small Canterbury stream. Mauri Ora, 3: 89-94.

Fumetti, S.V., P. Nagel \& B. Baltes. 2007. Where a springhead becomes a springbrook- a regional zonation of springs. Arch. Hydrobiol., 169(1): 37-48.

Graham, A.A., D.J. McCaughan \& F.S. McKee. 1988. Measurement of surface area of stones. Hydrobiologia, 157: 85-87.

Grant, P.J. 1977. Water temperatures of the Ngaruroro River at three stations. J. Hydrol., 16(2): 148-157.

Hawkes, H.A. 1975. River zonation and classification. In: Whitton, B.A. (Ed.), River Ecology. Blackwell Scientific Publications, Oxford: 312-374.

Hawkins, C.P. \& J.R. Sedell. 1981. Longitudinal and seasonal changes in functional organization of macroinvertebrate communities in four Oregon streams. Ecology, 62(2): 387397.

Hynes, H.B.N. 1970. The ecology of running waters. Liverpool University Press, Liverpool: $555 \mathrm{pp}$.

Johnson, F.A. 1971. Stream temperatures in an alpine area. $J$. Hydrol., 14: 322-336.

Lehmkuhl, D.M. 1972. Change in thermal regime as a cause of reduction of benthic fauna downstream of a reservoir. $J$. Fish. Res. Bd. Can., 29: 1329-32.

Maiolini, B. \& V. Lencioni. 2001. Longitudinal distribution of macroinvertebrate assemblages in a glacially influenced stream system in the Italian Alps. Freshwat. Biol., 46: 1625-1639.

McCabe, D.J. 1998. Biological communities in springbrooks. In: Botosaneanu, L. (Ed.), Studies in Crenobiology the Biology of Springs and Springbrooks. Backhuys, Leiden: 221-228.

McCune, B. \& M.J. Mefford. 1995. Multivariate Analysis of Ecological data, Version 2.0, Gleneden Beach, Oregon, USA: $126 \mathrm{pp}$.

Meffe, G.K. \& P.C. Marsh. 1983. Distribution of aquatic macroinvertebrates in three Sonoran Desert springbrooks. Journal of Arid Environments, 6: 363-371.

Michaelis, F.B. 1976. Physico-chemical features of Pupu Springs. N. Z. J. Mar. Freshwat. Res., 10(4): 613-628.

Milner, A.M. \& G.E. Petts. 1994. Glacial rivers: physical habitat and ecology. Freshwat. Biol., 32: 295-307.

Milner, A.M., R.C. Taylor \& M.J. Winterbourn. 2001. Longitudinal distribution of macroinvertebrates in two glacier-fed New Zealand rivers. Freshwat. Biol.., 46: 1765-1775.

Minshall, G.W. 1968. Community dynamics of the benthic fauna in a woodland springbrook. Hydrobiologia, 32: 305-339.

Minshall, G.W. 1984. Aquatic insect - substratum relationships. In: Resh, V.H. \& D.M. Rosenberg (Eds), The Ecology of Aquatic Insects. Praeger Publishers, New York: 358-400.

Perry, J.A. \& D.J. Schaeffer. 1987. The longitudinal distribution of riverine benthos: A river dis-continuum? Hydrobiologia, 148: 257-268.

Resh, V.H. 1983. Spatial differences in the distribution of benthic macroinvertebrates along a springbrook. Aquatic Insects, 5: 193-200.

SAS-Institute-Inc. 1988. Users Guide, Release 6.03 Edition. Cary, NC.

Sloan, W.C. 1956. The distribution of aquatic insects in two Florida springs. Ecology, 37: 81-98.

Smith, D.G. \& M.E. Lavis. 1975. Environmental influences on the temperature of a small upland stream. Oikos, 26: 228-236.

Smith, H. 2002. The hydro-ecology of limnestone springs of the Wye Valley, Derbyshire. Journal of the Chartered Institution of Water and Environmental Management, 16: 253-259.

Statzner, B. \& B. Higler. 1985. Questions and comments on the River Continuum Concept. Can. J. Fish. Aquat. Sci., 42: 1038-1044. 
Stefan, H.G. \& E.B. Preud'homme. 1993. Stream temperature estimation from air temperature. Water Resour. Bull., 29(1): 27-45.

Steinman, A.D. \& G.A. Lamberti. 1996. Biomass and pigments of benthic algae. In: Hauer, F.R. \& G.A. Lamberti (Eds), Methods in Stream Ecology. Academic Press, San Diego, California, USA: 295-313.

Sweeney, B.W. \& R.L. Vannote. 1978. Size variation and the distribution of hemimetabolous aquatic insects: Two thermal equilibrium hypotheses. Science, 200: 444-446.

Vannote, R.L. \& B.W. Sweeney. 1980. Geographic analysis of thermal equilibria: a conceptual model for evaluating the effect of natural and modified thermal regimes on aquatic insect communities. Am. Nat., 115(5): 667-695.

Vannote, R.L., G.W. Minshall, K.W. Cummins, J.R. Sedell \& C.E. Cushing. 1980. The river continuum concept. Can. J. Fish. Aquat. Sci., 37(1): 130-137.

Vinson, M.R. 2001. Long-term dynamics of an invertebrate assemblage downstream from a large dam. Ecol. Appl., 11(3): 711-730.

Ward, J.V. 1985. Thermal characteristics of running waters. Hydrobiologia, 125: 31-46.

Ward, J.V. 1994. Ecology of alpine streams. Freshwat. Biol., 32: $277-294$.

Ward, J.V. \& R.G. Dufford. 1979. Longitudinal and seasonal distribution of macroinvertebrates and epilithic algae in a
Colorado springbrook-pond system. Arch. Hydrobiol., 86(3): 284-321.

Ward, J.V. \& J.A. Stanford. 1979. Ecological factors controlling stream zoobenthos with emphasis on thermal modification of regulated streams. In: Ward, J.V. \& J.A. Stanford (Eds), The Ecology of Regulated Streams. Plenum Press, New York: 35-55.

Ward, J.V. \& J.A. Stanford. 1982. Thermal responses in the evolutionary ecology of aquatic insects. Annu. Rev. Entomol., 27: 97-117.

Winterbourn, M.J. 1997. New Zealand mountain stream communities: Stable yet disturbed? In: Streit, B., T. Stadler and C.M. Lively (Eds), Evolutionary Ecology of Freshwater Animals. Birkhauser Verlag, Basel/Switzerland: 32-54.

Winterbourn, M.J. 2000. Feeding ecology. In: Collier, K.J. and M.J. Winterbourn (Eds), New Zealand Stream Invertebrates: Ecology and Implications for Management. New Zealand Limnological Society, Christchurch: 100-124.

Winterbourn, M.J., J.S. Rounick \& B. Cowie. 1981. Are New Zealand stream ecosystems really different? N. Z. J. Mar. Freshwat. Res., 15: 321-328.

Winterbourn, M.J., K.L.D. Gregson \& C.H. Dolphin. 2000. Guide to Aquatic Insects of New Zealand, 13. Bulletin of the Entomological Society of New Zealand, Auckland: 102. 